\title{
Olfactory Bulb Granule Cell Aggregates: Morphological Evidence for Interperikaryal Electrotonic Coupling via Gap Junctions
}

\author{
Christian K. H. Reyher, ${ }^{1}$ Joachim Lübke, ${ }^{1}$ William J. Larsen, ${ }^{2}$ G. Michael Hendrix, ${ }^{2}$ Michael T. Shipley, ${ }^{2,3}$ and \\ Hans Georg Baumgarten" \\ 'Department of Neurobiology, Max-Planck-Institut für Biophysikalische Chemie, D-3400 Göttingen, Germany, ${ }^{2}$ Department \\ of Anatomy and Cell Biology and ${ }^{3}$ Department of Neurosurgery, University of Cincinnati, Cincinnati, Ohio 45267-0521, and \\ ${ }^{4}$ Department of Neuroanatomy, Institute of Anatomy, Freie Universität Berlin, D-1000 Berlin 33, Germany
}

Anaxonic interneurons of the granule cell type in the mammalian main olfactory bulb (MOB) are characterized by prominent membrane specializations, which include reciprocal, interdendritic chemical and electrical synapses; however, the latter are thought to be restricted to the external plexiform layer (EPL) and connect granule-mitral- and granuletufted-cell dendrites (Landis et al., 1974). The present study focuses on interperikaryal membrane specializations between tangentially oriented aggregates of granule microneurons in the lamina granularis interna (IGL). Both infraprimate (Rattus norvegicus, Gerbillus perpallidus) and primate species (Callithrix jacchus) were studied using the following methods: (1) transmission electron microscopy (TEM), (2) freeze-fracture analysis, (3) light and TEM immunohistochemistry using affinity-purified antibodies directed against the connexin-32 or connexin- 43 carboxy tail fragment of the gap-junction protein (GJP), and (4) intracellular Lucifer yellow injections in fixed tissue (LYF technique).

Freeze-fracture replicas of the MOB-IGL showed that adjacent granule cell perikarya have numerous particle aggregates on the cytoplasmic membrane; in terms of their structure and arrangement, such particles are characteristic of gap junctions. The existence of junctional membranes was substantiated by application of antibodies against GJP demonstrating punctate immunoreactivity, frequently confined to the interperikaryal plasmalemmae of granule cells in the IGL and their dendritic processes in the EPL. Upon TEM analysis, GJP-like immunoreactivity was additionaliy found in membranous organelles, including Golgi apparati and associated vesicular components. In order to test the permeability of identified membrane specializations, the LYF technique was used, which resulted in bright fluorescence of the perikaryal and dendritic components of the transsomatically injected neuron and staining of neighboring neurons with similar morphology. These findings imply that small molecules can diffuse across the interperikaryal membrane specializations.

\footnotetext{
Received Aug. 29, 1990; accepted Nov. 12, 1990.

We are very much indebted to Mrs. B. Frydel, R. Giessler, H. Krüger, S. Lausmann, and E. Nicksch for excellent technical assistance, Claudia Sanides for helpful discussions, and Berry Lee for comments on this manuscript. This work was supported in part by grants from the Deutsche Forschungsgemeinschaft (CR 30/19-1) and the Schering AG, Berlin.

Correspondence should be addressed to Dr. Christian K. H. Reyher, Abteilung für Neurobiologie, Max-Planck-Institut für Biophysikalische. Chemie, D-3400 Göttingen, Am Fassberg, Postfach 968, Germany.

Copyright (c) 1991 Society for Neuroscience $0270-6474 / 91 / 111485-11 \$ 03.00 / 0$
}

The existence of gap junctions between granule cell perikarya suggests that there is a significant, low-resistance electrical transmission between aggregated granule cells. This coupling might permit synchronization of neural discharge among small aggregates of these neurons. Gap junctions between granule cells may also serve signaling functions associated with the protracted period of granule cell development.

The modes of interneuronal communication that determine a neuron's functional role in microcircuitry include morphologically distinct channels and physiological mechanisms of information transfer across diverse types of junctions. Besides chemical synapses, it has been proposed that electrical synapses, that is, gap-junctional contacts, may play a role in information cxchange by providing direct electrical coupling and, possibly, intercellular transfer of small protoplasmic messenger molecules (Fraser, 1985). Since the initial analysis of the transmission of electrical impulses in both directions across anatomically defined membrane specializations in invertebrates (Lumbricus) by Bullock (1945), these junctions have been the subject of continuing interest. Among numerous investigators, the basic structural and geometric characteristics of gap junctions have been elaborated by Revel and Karnovsky (1967). The idea that gap junctions may represent functional contacts between neurons was substantiated by the demonstration of dye diffusion into coupled neurons in invertebrates (Stewart, 1978, 1981). Subsequent studies have shown that these membrane specializations are present in the mammalian CNS, suggesting that gap junctions are involved in the integrative properties of neural microcircuits in different brain regions, such as the hypothalamus (Andrew et al., 1981; Cobbett and Hatton, 1984), the hippocampus (Andrew et al., 1982; Katsumaru et al., 1988; Shiosaka et al., 1989; Yamamoto et al., 1989), or the inferior olivary nucleus (Sotelo et al., 1974; Benardo and Foster, 1986). The prevalence of gap junctions in the mature mammalian CNS, however, is still unclear. In the olfactory system, Landis et al. (1974) reported that gap junctions exist between granule cells and bulbar output neurons of the rat main olfactory bulb (MOB), thus forming dendrodendritic junctions, but details concerning their topographical distribution, quantity, and functional properties remain unexplored.

The granule cells of the mammalian MOB are interneurons that modify olfactory bulb signal processing by inhibitory modulation of bulbar output neurons (reviewed by Shepherd, 1972, 1979). Originally described by Golgi almost a century ago (Gol- 
gi, 1875), several morphological and developmental features of granule cells have been defined by subsequent investigators (Ramón y Cajal, 1911; Andres, 1965; Valverde, 1965; Hinds, 1968a,b; Price and Powell, 1970a,b; Scheibel and Scheibel, 1975; Kaplan and Hinds, 1977; Schneider and Macrides, 1978; Mori and Kishi, 1982; Mori et al., 1983; Orona et al., 1983; Kishi, 1987; Reyher, 1987; Frazier-Cierpial and Brunjes, 1989). The fact that granule cells lack an axon led to the question of how these cells were involved in the microcircuitry of the MOB. Rall et al. (1966) demonstrated that granule cells established contacts on the secondary dendrites of the olfactory bulb output neurons, the mitral cells, and a distinct population of tufted cells through dendritic specializations of the granule cells, the gemmules. These dendritic elements form bidirectional synaptic membrane complexes with mitral or tufted cell dendrites within the external plexiform layer (EPL); they may be excitatory (mitral-granulecell synaptic contacts) and inhibitory (granule-mitral-cell synaptic contacts) in close membrane proximity (Andres, 1965; Rall et al., 1966; Rall and Shepherd, 1968; Price and Powell, 1970a,b; Landis et al., 1974; Hinds and Hinds, 1976; Jackowski et al., 1978). In fact, the excitatory component of the bisynaptic junction of the granule cell gemmules onto the proximal mitral/ tufted cell dendrites constitutes the only output avenue of these interneurons (cf. Mori and Kishi, 1982).

Another striking feature of the organization of the internal granule cells that has received little attention is the frequent clustering of tangentially oriented adjacent granule cells. More detailed knowledge of their potential intersomatic connectivity may provide a key to understanding of the spatial distribution of inhibition channeled to groups of bulbar output neurons. Preliminary ultrastructural studies of the somata of such clustered granule cells in the rat MOB led to the unexpected observation that adjacent granule cell perikarya were extensively coupled via gap junctions (Reyher, 1987).

The objective of this study is to prove that gap junctions are a common structural feature of clustered granule cells in infraprimate and primate species; to reach this goal, a variety of morphological, immunohistochemical, and histophysiological techniques were applied to the MOB for detailed characterization of these junctional organelles. In concert, the present findings suggest that the vertical organization of granule-mitral-cell dendritic interactions may be significantly influenced by gap junctions between clusters of granule cells.

Preliminary results of this investigation were presented at the 1987 ECRO meeting (Reyher, 1987).

\section{Materials and Methods}

Animals. The material was obtained from 17 adult rats (body weight, $160-250 \mathrm{gm}$ ), 5 adult gerhils (hody weight, $60-80 \mathrm{gm}$ ), and 6 marmosets (body weight, 230-280 gm; a gift from Professor J. R. Wolff, Department of Anatomy, University of Göttingen, Germany). The marmoset and gerbil brains were prepared for transmission electron microscopy (TEM). In addition, rat material was used for freeze-fracture analysis $(n=3)$, transmission electron microscopy $(n=3)$, immunohistochemistry $(n=$ 6 ), and intracellular Lucifer yellow (LY) injections ( $n=5$ ).

Anesthesia. Rodents were deeply anesthetized with sodium pentabarbital (Nembutal; $40-90 \mathrm{mg} / \mathrm{kg}$ body weight, i.p.); for primates, a mixture of ketamine $\mathrm{HCl}$ (Ketanest), xylazine, and midazol $\mathrm{HCl}$ (Dormicum, 12:0.8:0.1 mg/ $\mathrm{kg}$ body weight, i.m.) was used.

Histology. The animals were transcardially perfused with phosphatebuffered [0.05 $\mathrm{M}$ phosphate buffer ( $\mathrm{PB}) ; \mathrm{pH}, 7.4$ ] physiological saline containing heparin (Liquemin, 25,000 IU) followed by a mixture of $4 \%$ paraformaldehyde and $0.5 \%$ glutaraldehyde in $0.1 \mathrm{M} \mathrm{PB}(\mathrm{pH}, 7.4 ; 20$ $45 \mathrm{~min}$ ). The brains were usually left in situ for the next $4 \mathrm{hr}$. The MOB was then prepared for the different techniques as described below.
For TEM analysis, the MOB material was cut at a vibratome (Oxford Instruments, UK) into $120-\mu \mathrm{m}$-thick coronal or parasagittal sections. After several rinses in $0.1 \mathrm{M} \mathrm{PB}(\mathrm{pH}, 7.4)$, sections were transferred for $1 \mathrm{hr}$ into $0.1 \%$ cacodylate buffer $(\mathrm{pH}, 7.4)$ containing $0.5-2 \%$ tannic acid. The postfixation and embedding procedure was adopted from the original protocol of Larsen et al. (1979) and Heimer and Robards (1982). $\Lambda$ fter several rinses in the same buffer, the scctions wcre transferred into $1 \%$ osmium tetroxide for $2 \mathrm{hr}$. This was followed by an ascending series of ethanol and embedding in Epon 812 or an Epon 812/Araldite mixture. The material was cut in a Reichard Ultracut microtome $(0.5-\mu \mathrm{m}$ sections) and stained with toluidine blue to identify the internal granule cell layer (IGL) of the MOB. Single ultrathin sections were counterstained in a saturated uranyl acetate solution for $20 \mathrm{~min}$ and lead citrate (Reynolds Reagenz) for 5-8 min. The material was examined and analyzed with a Zeiss EM 10 electron microscope.

Freeze-fracture analysis. For freeze-fracture analysis, the animals were deeply anesthetized, and the untreated brains were removed from the skull. Blocks containing the IGL of the MOB were subsequently prepared and immersion fixed by $2.5 \%$ glutaraldehyde in $0.05 \%$ cacodylate buffer $(\mathrm{pH}, 7.4)$ for $10 \mathrm{~min}$. After several rinses in the same buffer, the samples were infiltrated in $30 \%$ glyccrol betwcen 2 gelatin-filled $(6 \%)$ Balzors mirror-image sample holders. The sections were then transferred into Freon, inserted into a mirror-image device, and fractured in a Balzers 301 freeze-fracture apparatus. Grids were examined in a Jeol $100 \mathrm{CX}$ electron microscope.

Immunohistochemistry. Affinity-purified antibodies directed against the connexin-32 or connexin-43 carboxy tail fragment of the gap junction protein (GJP) were used. The production of these antibodies has been previously described (G. M. Hendrix, C. Skowron-Lomneth, W. Wilfinger, E. L. Hertzberg, S. S. T. Mao, C. Chen, and W. J. Larsen, unpublished observations).

Based on a gap junction protein amino acid sequence (Paul, 1986), 2 hydrophilic amino acid sequences were synthesized and subsequently prepared for immunization. Antisera generated against both of these fragments bind to purificd gap junction protein in Western blot analysis, and the binding is inhibited by preincubation of the antibody with synthetic peptide antigen (Hendrix et al., unpublished observations). Preincubation of the antibody with synthetic peptide antigen blocks this reaction. In certain CNS regions, for example, the anterior olfactory nucleus, the antibodies used stained cell nuclei in addition to gap junctions. The reason for immunoreactivity at the level of the cell's nucleus is at present obscure. This study focuses on immunoreactivity that is confined to plasma membranes.

For preembedding TEM immunohistochemistry, adult rats were used. After a brief perfusion with $0.9 \%$ saline in $0.1 \mathrm{M} \mathrm{PB}(\mathrm{pH}, 7.4)$, the animals were transcardially perfused with $0.1 \mathrm{M} P B(\mathrm{pH}, 7.4)$ containing $4 \%$ paraformaldehyde and $0.05 \%$ glutaraldehyde for $60 \mathrm{~min}$. The brains were left in situ for the next $2 \mathrm{hr}$. The MOB was removed and cut with a freezing microtome into $25-\mu \mathrm{m}$-thick frontal and parasagittal sections. Alternatively, TEM immunohistochemistry was carried out on $80-\mu \mathrm{m}$ thick vibratome sections. Sections were collected in $0.1 \mathrm{M} P B(\mathrm{pH}, 7.4)$. The tissue was preincubated for $20 \mathrm{~min}$ in $0.1 \mathrm{M} \mathrm{PB}(\mathrm{pH}, 7.4)$ containing $0.9 \%$ sodium chloride (PBS), $0.8 \%$ bovine serum albumin (BSA), $5 \%$ normal goat serum, $0.1 \%$ gelatin (IGSS quality gelatin, Janssen Lab), and $2 \mathrm{~mm}$ sodium azide, and then transferred into the primary antisera against the synthetic fragment of connexin-32 or connexin- 43 of the gap junction protein (dilution, 1:1000) containing 1\% normal goat serum and $0.02 \%$ sodium azide and left at $4^{\circ} \mathrm{C}$ overnight [in one case, the primary antisera contained $0.01 \%$ Triton-X100, which resulted in a stronger GJP-immunoreactive (GJP-IR) signal]. After several rinses in $0.1 \mathrm{M} \mathrm{PB}(\mathrm{pH}, 7.4)$, the sections were incubated for $45 \mathrm{~min}$ in goat antirabbit IgG (dilution, 1:50; Vector Lab) and in avidin-biotin complex (Vector Lab), respectivcly. After several rinses in $0.1 \mathrm{M} \mathrm{PBS,} \mathrm{the} \mathrm{sections}$ were immersed for 5-7 min in a solution containing $200 \mathrm{mg}$ diaminobenzidine (DAB; Grade II, Sigma) per $1000 \mathrm{ml} 0.05 \mathrm{M}$ Tris $\mathrm{HCl}$ buffer $(\mathrm{pH}, 7.4)$, and $150 \mu \mathrm{l} 3 \% \mathrm{H}_{2} \mathrm{O}_{2}$; the DAB reaction was stopped by repeated treatment with $0.1 \mathrm{M} \mathrm{PB}(\mathrm{pH}, 7.4)$. To enhance staining contrast, sections were briefly postfixed in an aqueous solution of $1 \%$ osmium tetroxide. Alternatively, material for the TEM analysis of immunogold-stained cell compartments was processed as follows: after the initial procedures (preincubation and incubation), the sections were treated with the secondary antibody (dilution, 1:50 in the incubation buffer; $4 \mathrm{hr}$; AuroProbe One, Janssen Lab). After several rinses in 0.1 M PB (pH, 7.4), the sections were postfixed in $2 \%$ glutaraldehyde in 0.1 M PBS (pH, 7.4) for $10 \mathrm{~min}$. After excess washing in distilled water, sections were transferred into the silver enhancement kit (Intense SEM, 
Janssen Lab) for 10 min. The reaction was stopped in $\mathrm{H}_{2} \mathrm{O}$. Sections were mounted, dehydrated, and coverslipped (Merckoglas, E. Merk) for light microscopy. In addition, material was prepared for TEM as described above.

Lucifer yellow injections. In order to demonstrate dye coupling between adjacent granule cells, individual neurons were intracellularly injected with Lucifer yellow (LY; a 4-aminonaphthalimide substituted with 2 sulfonate groups), which does not pass easily through nonjunctional membranes (Stewart, 1978). The methodology used corresponds to an extended protocol originally published by Buhl and Lübke (1989). Perfusion was carried out as described above. The olfactory bulb was blocked with a nontoxic glue (Histoacryl) and serially cut into $120-\mu \mathrm{m}$ parasagittal sections in a vibratome (Dosaka Instruments, Japan). Slices not required for immediate injections were stored in $0.1 \mathrm{MPB}(\mathrm{pH}, 7.4)$ at $4^{\circ} \mathrm{C}$. In this material, excellent staining quality was obtained for periods of up to $14 \mathrm{~d}$. Prior to mounting for LY injections, slices were incubated for 5-10 $\mathrm{min}$ in a $10^{-7} \mathrm{M}$ aqueous solution of the DNA stain 4,6-diamino-2-phenylindol (DAPI; Sigma). This staining procedure resulted in brightly fluorescent nuclei, which provided a suitable target for the LY-filled pipettes (tip diameter, 0.5-1 $\mu \mathrm{m}$; resistance, $80-150$ $\mathrm{M} \Omega$ ). Slices were mounted onto a slide and transferred into the injection chamber containing $0.1 \mathrm{M} \mathrm{PB}(\mathrm{pH}, 7.4)$. The chamber was then attached to the stage of a microscope. Because of the absence of electrophysiological criteria to monitor the successful penetration of neurons, epifluorescence illumination (Zeiss filter combination for LY) was essential for visual guidance of the LY pipette and control of the dye injection. After successful impalement of a granule cell body or a primary dendrite, dye was injected iontophoretically with a constant negative current of 1-3 nA for 3-10 min. Dye filling of a granule cell was considered to be complete when fine distal processes appeared brightly fluorescent and adjacent cells were observed to be filled with the dye. To transform LY into a stable and light-microscopically visible reaction product, slices with LY-filled granule cells of the MOB were preincubated for 5-10 min in $0.1 \mathrm{M}$ PB containing $1.5 \mathrm{mg} / \mathrm{ml} \mathrm{DAB}$. For the detailed description of this methodology, see Buhl and Lübke (1989). Sections werc cxamined and photographed using a Leitz Dialux 20 microscope. Additionally, individual neurons were analyzed by graphical reconstruction with a camera lucida.

\section{Results}

Structural features of internal granule cells

The arrangement of granule cells in the MOB-IGL in 3 different species (rat, gerbil, and marmoset) was investigated by means of light microscopic and TEM techniques, in order (1) to demonstrate general morphological features of granule cells (the most common cell type in the IGL) in the mammalian MOB and (2) to examine the morphological correlate of interperikaryal lowresistance channels (gap junctions) between internal granule cells. The analysis of the MOB-IGL in the three different mammals studied so far has revealed that granule cells are frequently organized in groups of tangentially arranged clusters. Figure 1 shows the typical distribution pattern and arrangement of granule cells in superficial (Fig. $1 A$ ) and deep parts (Fig. $1 B$ ) of the IGL. Neurons organized into clusters were identified as follows: they are regularly bipolar in shape with small, mostly round or spherically shaped somata. Their cell diameters ranged from 6 to $11 \mu \mathrm{m}$. In addition, single neurons with similar morphology, but not in soma-to-soma contact to neighboring granule cells, were found in the neuropil of the IGL (Fig. 1A). Granule cell clusters were typically separated by about $25-60 \mu \mathrm{m}$ in the centroperpendicular direction.

Because we did not see striking interspecies differences in the organization of granule cells, the present account focuses upon features of granule cells common to these mammals. Representative examples of ultrastructural observations based on both transmission and freeze-fracture electron microscopic methods are shown in Figure 1, $C$ and $D$, demonstrating granule cells in the primate MOB (Fig. 1C) and those of the rat MOB (Fig. 1D).
The granule cell bodies were largely occupied by the nucleus, which appeared relatively dark as a result of the condensed chromatin material at the nuclear membrane and the presence of prominent nucleoli, which tended to be in close proximity to the nuclear membrane. Another characteristic feature of the granule cells is the relatively small rim of cytoplasm (Fig. $1 C$, $D$; see also Fig. $3 A$ ) surrounding the nuclei. Occasionally, the outer membrane of the perinuclear space was found to be in close proximity to the interior aspect of the plasma membrane. The cytoplasm contained little endoplasmic reticula, free ribosomes, Golgi fields, mitochondria, dense vesicular and multivesicular bodies, and a few neurotubules.

A general feature of internal granule cells is the existence of specialized parts of the plasmalemma that connect adjacent granule cells by various types of appositional complexes. In tannic acid-fixed material, the perikaryal membranes of two adjacent internal granule cells were linked by desmosomes. In addition, adjacent perikaryal membranes established typical gap junctions (see Fig. $3 A$ ). In freeze-fracture material (Fig. $2 A, B$ ), the P-face displayed an array of about 9-nm particles with a center-to-center distance of about $12 \mathrm{~nm}$. The criteria of gap junctions (uniformity of the particle diameter, close packing of the particles, and position on slight bulges of the membrane) were thus fulfilled in such profiles. In addition, particularly in the primate $\mathrm{MOB}$, but also in the rodent $\mathrm{MOB}$, gap junction vesicles (micrograph not shown) were seen (in TEM pictures) that were completely separated from the cell surface; granule cells containing such vesicles were also distinguished by a small rim of condensed intracellular electron-dense material. Within these vesicles, sectioned filaments could occasionally be observed. Dense plaques, mostly oriented towards the nuclear membranes or pores, were also present.

\section{Immunocytochemical demonstration of gap junctions}

Antibodies directed against either the GJP-connexin-32 or GJPconnexin-43 carboxy tail fragment resulted in GJP-like immunoreactivity distributed throughout all layers of the rat MOB, including the olfactory nerve layer. Both antibodies gave a similar pattern of staining. Both neuronal and glial elements were GJP-IR. Besides numerous glial structures including GJP-positive glial gap junctions, GJP immunoreactivity was confined to neuronal cell bodies (cf. Fig. $3 B$ ) and neural processes (gemmules, dendritic varicosities, and membraneous organelles).

At the light microscopic level, numerous GJP-IR granule cells were identified in the IGL, the mitral cell layer, and the periglomerular sheet (Fig. 3B). However, little immunoreactivity was found within the glomerula. In general, GJP immunoreactivity was enriched in the layers of the MOB that harbor many neuronal somata, that is, the mitral cell layer (surrounding the nonGJP-IR mitral and deep tufted cells) and the IGL (Fig. 3B). Within the EPL, a rather homogeneous and relatively dense distribution of GJP-IR sites was observed, in contrast to the sparse distribution of immunoreactivity within the internal plexiform layer (IPL; Fig. $3 B$ ). In the EPL, the density of GJP immunoreactivity formed a gradient, light in the deep EPL and dense in the superficial part of this layer.

In semithin sections, GJP immunoreactivity appeared in a punctate pattern within both cell bodies and neuropil in the form of isolated punctate deposits of reaction product. Among neuronal elements within the IGL, GJP-IR precipitates appeared to be largely restricted to the interfaces of adjacent granule cell perikarya (Fig. $3 C, D$ ) forming punctate immunoreactive 

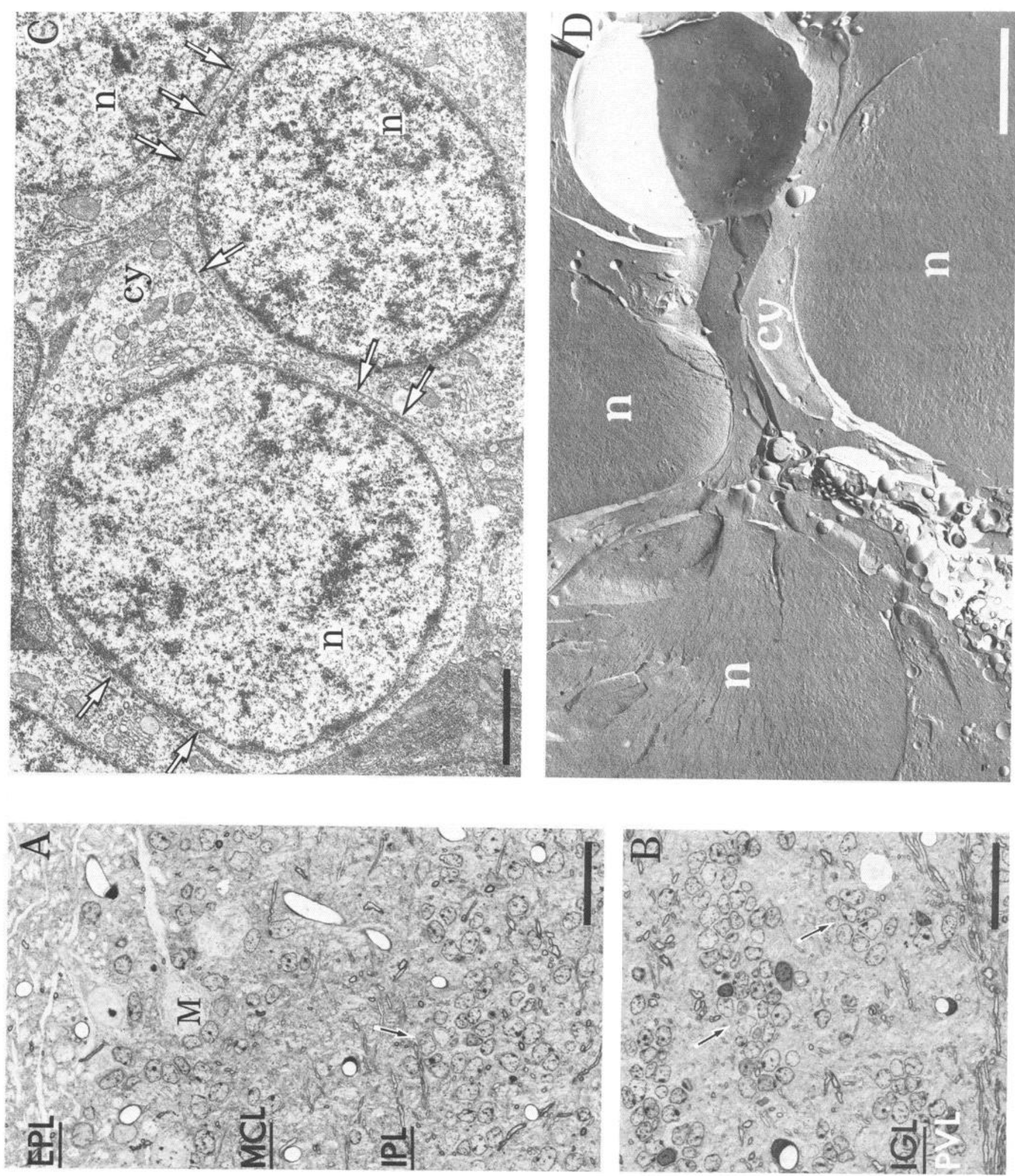


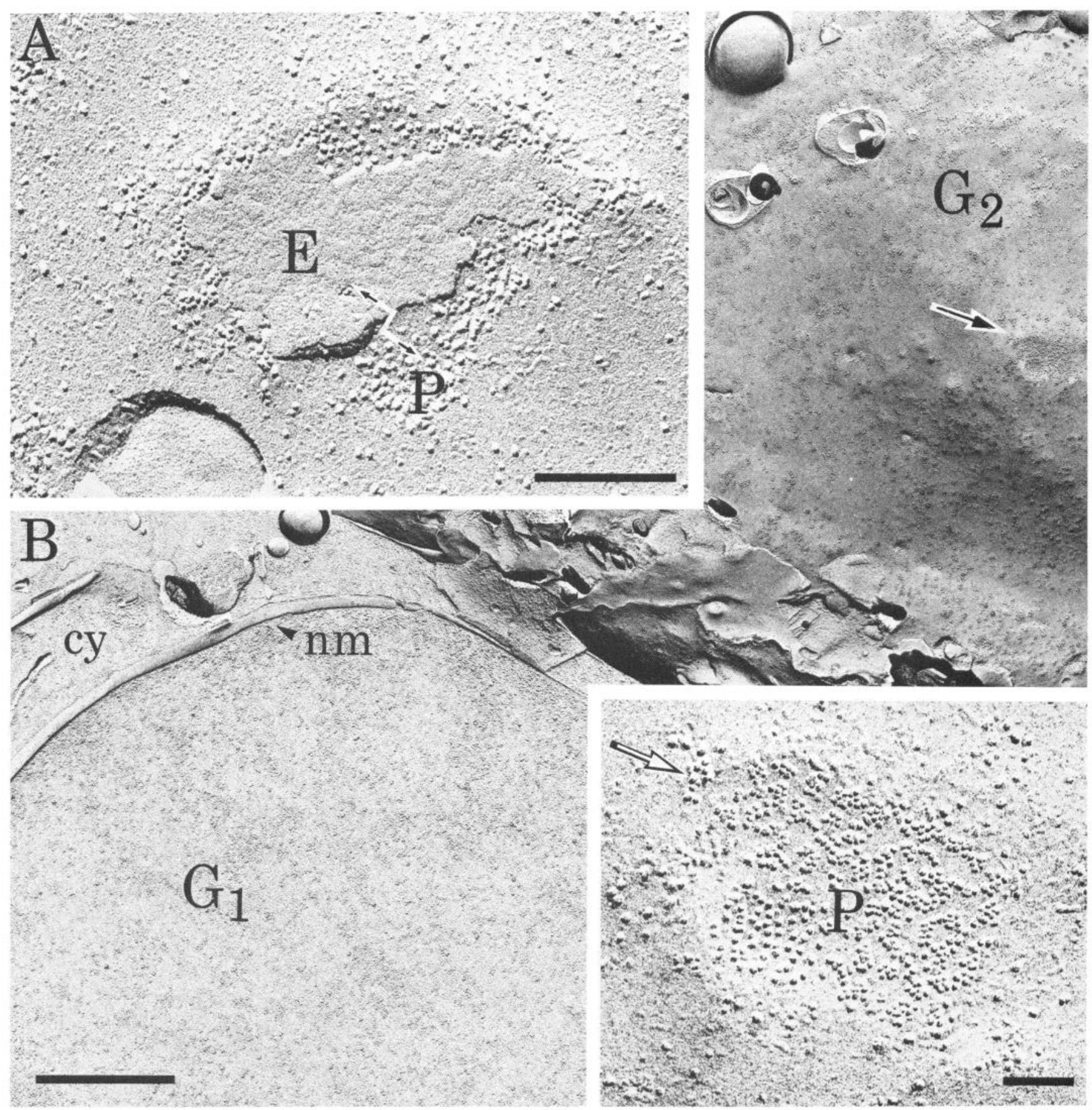

Figure 2. A, Neural gap-junctional contact in the IGL of the rat MOB: the characteristics of the gap junction organelle; the P-fracture face intramembranous particles $(P)$ and E-fracture face pits $(E)$ are evident. Scale bar, $200 \mathrm{~nm}$. $B$, Freeze-fracture replica of adjacent granule cells $\left(G_{I}\right.$, $\left.G_{2}\right)$ of the MOB-IGL in the rat. The inset shows P-fracture-face intramembranous particles $(P)$ of granule cell $G_{2}(B$, arrow $)$ at higher magnification. $c y$, cytoplasm; $n m$, nuclear membrane. Scale bars: $A, 200 \mathrm{~nm} ; B, 2 \mu \mathrm{m}$.

Figure 1. $A$ and $B$, Photomicrographs depicting the distinct laminar pattern of the MOB in the rat. Note the formation of aggregates of granule cells (arrows) within the IGL (Epon-embedded sagittal section; thickness, $0.5 \mu \mathrm{m}$ ). $M$, mitral cell; $M C L$, mitral cell layer; $P V L$, periventricular layer. Scale bars, $50 \mu \mathrm{m}$. $C$ and $D$, Electron micrographs from the MOB-IGL demonstrating 3 adjacent perikarya of granule cells in the marmoset ( $C$; tannic acid/glutaraldehyde fixation method) and in the rat ( $D$; freeze-fracture technique). Arrows in $C$ point to areas of close membrane contact. cy, cytoplasm; $n$, nucleus. Scale bars, $2 \mu \mathrm{m}$. 

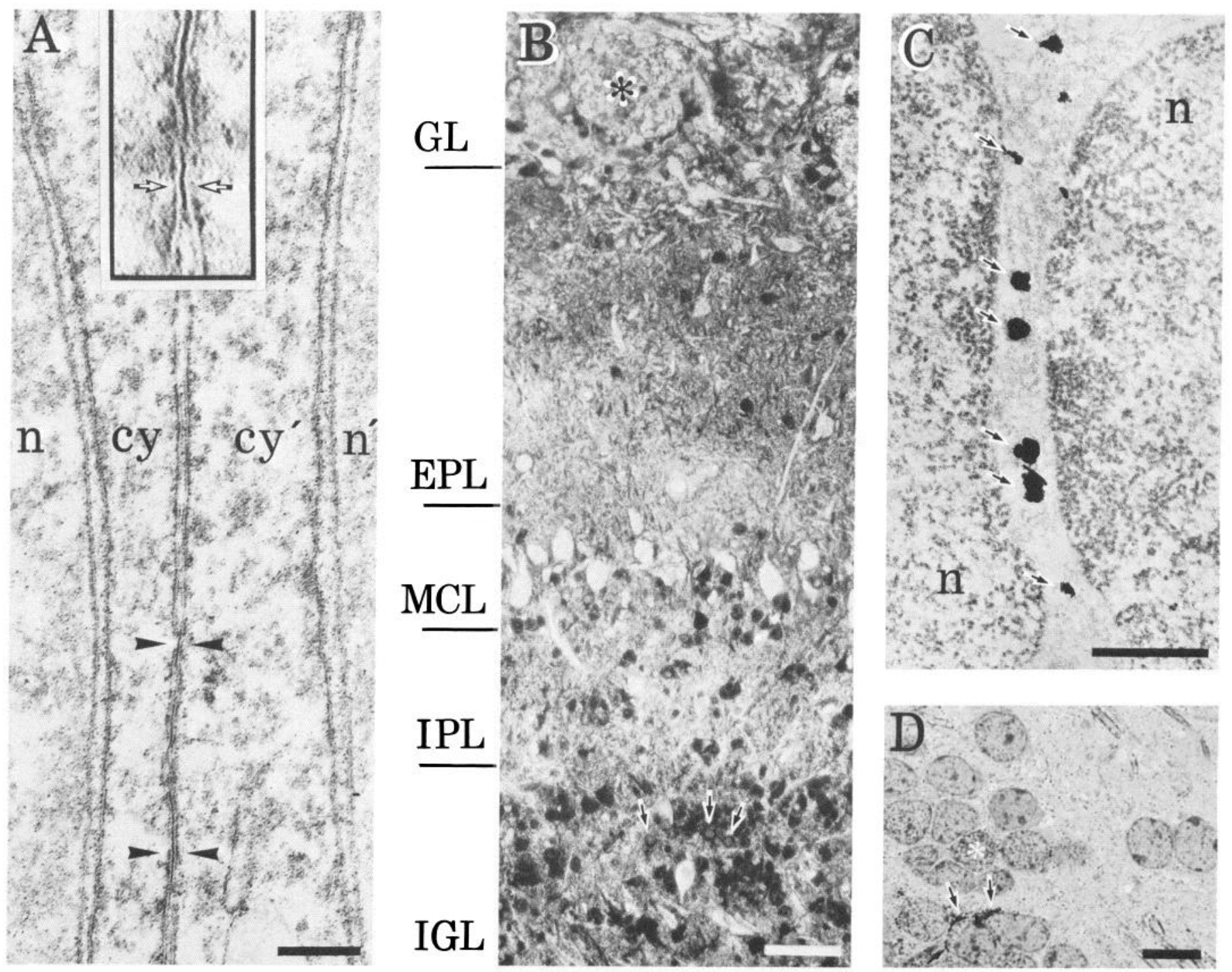

Figure 3. A, Electron micrograph shows the profile of gap junctions coupling two adjacent granule cell perikarya of the most superficial portion of the IGL of the MOB in the microsmatic primate Callithrix jacchus. Arrows (inset) and arrowheads point to gap junctions. Note the regular arrangement of gap junction complexes. $c y$, cytoplasm; $n$, nucleus of granule cell. Scale bars: $A, 250 \mathrm{~nm}$; inset, 87,000 $\times$. B, Low-power photomicrograph of a sagittal section $(80 \mu \mathrm{m})$ of the rat MOB depicting the distribution pattern of GJP-like immunoreactivity. Note the dense immunostaining of diverse types of microneurons (e.g., granule cells, arrows) and uniform distribution of GJP immunoreactivity in the EPL and IPL. Asterisk indicates a glomerulus. $G L$, glomerular/periglomerular layer; $M C L$, mitral cell layer. Scale bar, $100 \mu \mathrm{m}$. $C$, Electron micrograph demonstrating the zone of contact of two adjacent granule cell perikarya. Black spots (arrows) are the immunohistochemical reaction products (immunogold-silver precipitates) that were used to facilitate location of GJP-like particles in the outer cellular membrane. $n$, nucleus of granule cell. Scale bar, $1 \mu \mathrm{m}$. $D$, High-power interference-contrast photomicrograph showing the distribution of GJP-like immunoreactivity in the rat IGL. Note the prominent punctate appearence of immunoreactivity at the limits of granule cell perikarya (arrows). The asterisk labels a tangentially cut granule cell. Scale bar, $10 \mu \mathrm{m}$.

elements linearly arranged at the granule-granule-cell cytoplasmic membranes. Correlative light microscopic and TEM analysis in terms of morphological criteria (cf. Price and Powell, 1970a) consistently indicated that the GJP-IR neurons are granule cells. However, a few nonreactive cells were found within granule cell clusters of the IGL. At the electron microscopic level, the GJP reaction product appeared as electron-dense granules of different size, either rounded in shape or rodlike and elongated. GJP immunoreactivity was frequently confined to the entire membrane area at sites of granule-granule cell-body contacts (Fig. 3C). In addition, GJP immunoreactivity was found to a much lesser extent in the membrane-close areas of cytoplasm and the Golgi complex and within dendritic varicosities in about 30-40-nm cytoplasmic vesicles (photomicrograph not shown).

\section{Intracellular Lucifer yellow injections}

To determine whether there was dye coupling between internal granule cells via gap junctions, LY was injected into single perikarya. Several intracellular LY injections were made into the IGL of the rat MOB in $120-\mu$ m-thick fixed brain slices. Only neurons with dendritic staining that was considered complete were included in our sample. Neurons were identified as internal granule cells by the following critria: (1) typical arrangement and ramification of the apical and basal dendritic tree (according to Mori et al., 1983) and (2) a complex distribution of several 

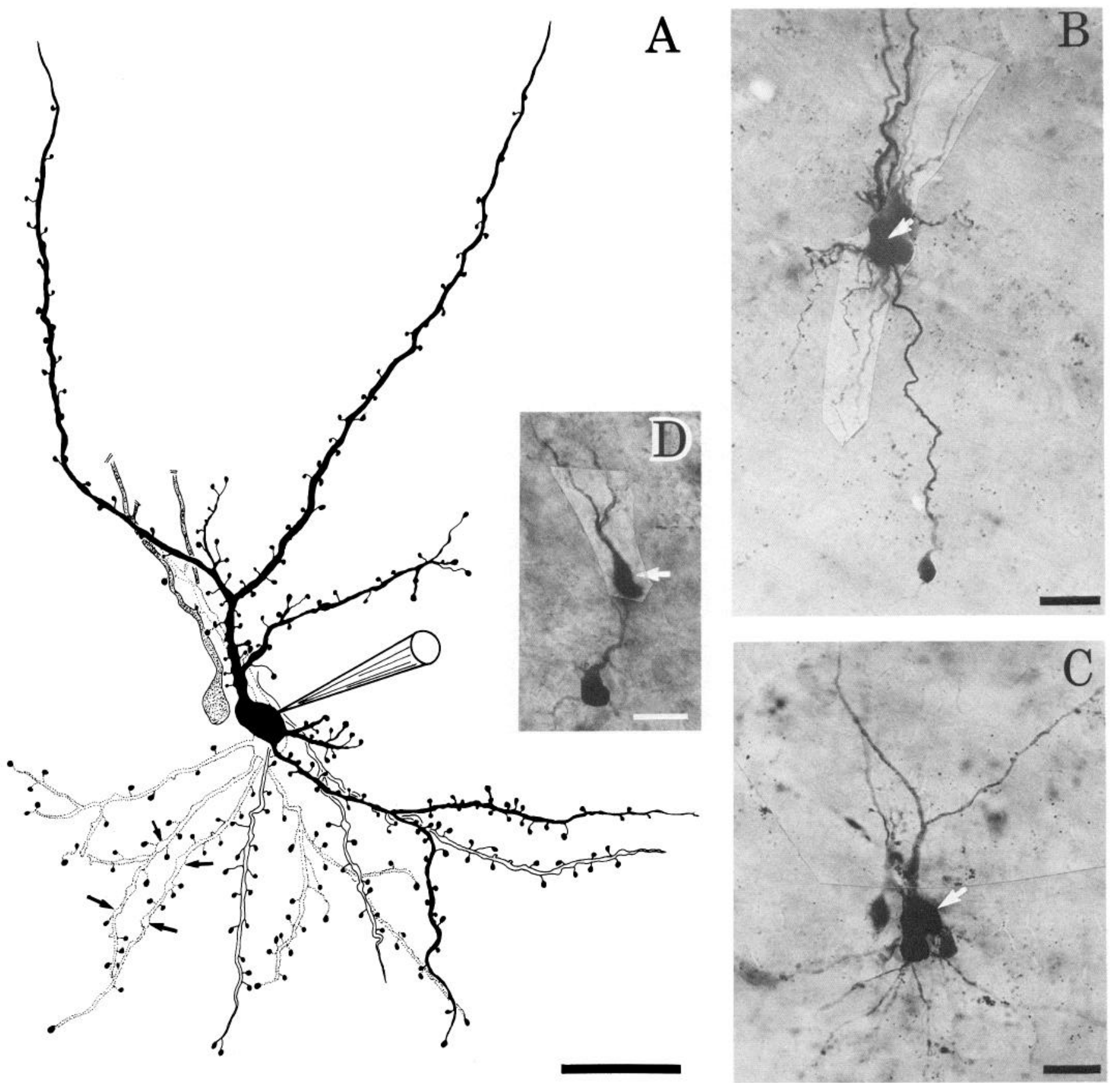

Figure 4. A, Camera lucida drawing of an individual LY-injected granule cell (micropipette impaled) in the rat MOB-IGL and three of its costained neighbors arborizing within the IGL, IPL, and EPL (cf. C). The shape of the LY-filled neurons is coincident to the known outline of granule cells identified by Golgi or tracing methods. Scale bar, $25 \mu \mathrm{m}$. $B$ and $D$, Granule cells in the rat MOB-IGL demonstrated by the Lucifer yellow technique. Note the transdendritic staining of granule cells in contact over a distance of about $250 \mu \mathrm{m}$. Arrows point to LY-injected cells. Scale bar, $25 \mu \mathrm{m}$. $C$, Photomicrograph demonstrating the same labeled, clustered granule cells in the rat MOB reconstructed in the camara lucida drawing in $A$. Scale bar, $25 \mu \mathrm{m}$.

distinct types of spinelike protrusions, including spines, gemmules, and varicosities. A representative sample of injected neurons in the IGL is shown in Figure 4. In addition, a detailed camera lucida drawing made from the same cell cluster depicted in Figure $4 C$ demonstrates the effectiviness of the dye filling, as well as the clustered arrangement of granule cells in the IGL.

When injected into neurons, LY effectively stained the entire dendritic tree and remained confined to the cellular boundaries
(Fig. 4B-D). Higher magnification of the injected cells revealed that the dye had spread into the entirety of the apical and basal dendrites. The apical dendrites, which had spinelike protrusions and gemmules, ascended towards the pial surface, passing the IPL and the mitral cell layer and terminating in the EPL, whereas the basal dendrites, characterized by varicosities, were radially oriented within the IGL (cf. Fig. 4A). The intracellular filling of a granule cell with LY resulted not only in the complete filling 
of the impaled neuron, but also in the spread of dye into 3-5 adjacent neurons belonging to the same cell cluster (Fig. 4B,C). This phenomenon was observed in all of the granule cells injected. In addition, the dye coupling was not restricted to perikaryal contacts; it was also traced to neurons that did not belong to the same granule cell cluster, implying that dye had penetrated dendrodendritic and dendrosomatic contacts. Cells stained in this way werc separated by distances up to $120 \mu \mathrm{m}$ (cf. Fig. $4 C, D)$. The LY injections give indirect evidence for electrotonic coupling of internal granule neurons of the rat MOB, connected by soma-to-soma and soma-to-dendrite junctions via specialized dye-permeable membrane complexes.

\section{Discussion}

The present study demonstrates that olfactory bulb intrinsic granule cells of the IGL organized into closely apposed tangentially oriented clusters are mutually coupled via gap junctions in both infraprimate and primate species. Original evidence for intersomatic gap junction specializations between granule cell bodies was obtained by ultrastructural analysis (Reyher, 1987). These initial findings are supplemented here by freeze fracture and by light microscopic and TEM immunohistochemistry using antibodies (conncxin-32 and connexin-43) directed against 2 hydrophilic amino acid sequences (Paul, 1986) of synthetic gap junction polypeptides (Hendrix et al., unpublished observations). In addition, the results of the LY-filling technique support the idea that this structural feature is the morphological correlate of electrotonic coupling of adjacent granule cells. The frequent occurrence of neural gap junctions in the MOB-IGL, together with the modular arrangement of IGL granule cell somata, may therefore reflect the existence of electrically coupled functional units influencing the signal processing in MOB output neurons.

The several lines of evidence reported here suggest that gap junctions are a fundamental specialization in the mammalian olfactory bulb. However, it is not yet known if these membrane specializations are restricted to a distinct subpopulation of granule cells. The pattern of distribution of the GJP immunoreactivity within the IGL (i.c., the decreasing density gradient from superficial to central parts within the EPL and IGL) suggests that gap junctions may be confined to the dark granule cell subpopulation because light granule cells are more frequently clustered in central parts of the IGL (Struble and Walters, 1982). This assumption is substantiated by the dendritic characteristics of the gap junction neurons.

Even now, there is surprisingly little information on the structure, distribution, and function of gap junctions in the mammalian brain; this has led to the general belief that these organelles are rare in the CNS. However, several reports have described gap junctions in CNS structures such as the hippocampal formation (CA3 field, Schmalbruch and Jahnsen, 1981; polymorph layer of the dentate gyrus, Kosaka, 1983), the retina (bipolar ganglion cells, Dowling and Boycott, 1966; horizontal cells, Raviola and Gilula, 1975), cerebellar cortex (Sotelo and Llinás, 1972), and the inferior olivary nucleus (Sotelo et al., 1974; Benardo and Foster, 1986). Evidence for the existence of random membrane junctions connecting proximal dendrites of mitral and tufted cells with granule cell dendrites within the EPL was published by Landis et al. (1974). More recently, the immunocytochemical demonstration of GJP fragments in CNS tissue (Shiosaka et al., 1989; Yamamoto et al., 1989) has provided an excellent semiquantitative methodology for mapping of the distribution pattern of such organelles over wide regions of the brain and suggests that electrical coupling throughout the mammalian brain may be more common than is currently thought. The antibodies used here are able to recognize immunohistochemically the connexin-32 and -43 carboxy tail fragments of the GJP detected in the brain by Western blot analysis. This is the first investigation that traces these GJP antibodies in CNS tissue by immunohistochemistry. The TEM features of the GJPIR structures reveal them as typical gap junctions.

Gap junctions have been related to a number of physiological phenomena suggesting that these organelles are involved in cellcell signaling. Two of the more intriguing properties of gap junctions are (1) that low-molecular-weight compounds can pass between coupled cells and (2) that gap junctions provide a lowresistance electrical channel between coupled cells. Gap junctions between neurons have both of these properties (Bennett and Goodenough, 1978). The present findings are in agreement with recent studies that describe the phenomenon of dye coupling between neurons in in vitro preparations of neocortical slices (Gutnick and Prince, 1981), hippocampal slices (Andrew et al., 1982; Knowles et al., 1982), and rat hypothalamic slices (Andrew et al., 1981; Cobbett and Hatton, 1984). However, dye coupling among MOB granulc cclls was observed in all cases, which is in contrast to our recent observation that coupling is rare in fixed neocortical slice preparations (Buhl and Lübke, 1989). This discrepancy can be explained by assuming that granule cells of the MOB are more frequently coupled via gap junctions than pyramidal neurons of the neocortex.

What might be the functional significance of gap junctions between granule cells? Electrophysiological experiments indicate that granule cells are inhibitory interneurons that powerfully modulate, via both feedforward and feedback inhibitory control, the activities of mitral and tufted cells (Rall et al., 1966; Mori and Takagi, 1978). Neurochemical and neuropharmacological studies suggest that this inhibitory effect may be mediated by GABA (e.g., McLennan, 1971; Nicoll, 1971; Austin et al., 1979); in fact, $\gamma$-aminobutyrate, glutamic acid decarboxylase, methionine-enkephalin, and substance $P$ can be localized within granule cells and their processes (Ribak et al., 1977; Halász ct al., 1979; Bogan et al., 1982; Burd et al., 1982; Davis et al., 1982; Jaffé et al., 1983; Mugnaini et al., 1984; Baker, 1986a,b; Kosaka et al., 1987; Matsutani et al., 1988, 1989). Both a stratified organization in GABAergic subsystems within the olfactory bulb and the possible coexistence of various neuroactive substances within granule cells have been recently discussed (Kosaka et al., 1987).

According to Price and Powell (1970c) and Reyher et al. (1988), the shafts and spines of granule cells are the major postsynaptic targets of incoming associational and commissural fibers from the anterior olfactory nucleus of both rodents and primates (Reyher, 1988; C. K. H. Reyher, unpublished observations). These inputs are organized in a laminar fashion and contact granule cell dendritic gemmules via type I synaptic junctions, providing a substrate for presynaptic control of the dendritic protrusions. In addition, granule cells probably receive dircct intrinsic axonal input from mitral cells via type I synapses (Price and Powell, 1970c), and the dendrites of granule cells receive excitatory dendrodendritic synapses from the mitral/tufted cells (Rall et al., 1966). Shepherd (1972) postulated that the dendrodendritic synaptic pathway between granule and mitral cells provides spatially organized self- and lateral inhibition (Fig. 5). 
One potential role of interperikaryal gap junctions may comprise coordination of activity in coupled granule cells. Thus, these membrane specializations might function, in particular, to convert incoming streams of centrifugal signals into spatially and temporally coordinated patterns of granule cell action such that the granule-mitral-cell inhibitory linkage becomes synchronized.

Studics in the inferior olive (Llinás et al., 1974; Sotelo et al., 1974; Benardo and Foster, 1986) suggest that gap junctions between inferior olivary neurons may function to coordinate aggregates of neurons that generate oscillatory patterns of excitation/inhibition. In this context, it is worth noting that a characteristic feature of olfactory bulb function is its synchronous, rhythmical activity during sniffing and olfactory processing. Recent studies have shown that sniffing rates, olfactory bulb slow EEG waves, unit firing patterns, and limbic $\theta$ rhythms are frequently phase locked during exploratory sniffing and odor discrimination learning (Macrides et al., 1982). These coordinated rhythms require centrifugal inputs to the olfactory bulb, which, as recent studies have shown, are directly or indirectly targeted to the granule cells (Nickell and Shipley, 1988; McLean et al., 1989). The coordination of oscillatory activity throughout the MOB might be mediated at least in part by electrical coupling between granule cells.

Gap junctions in the MOB may also have important functions during development. Recent studies of the developing neocortex indicate that during the earliest phase of postnatal development up to $70 \%$ of the cortical neurons in slice preparations exhibit dye coupling; after maturation, it decreases to only $20 \%$ (Connors et al., 1983). It is suggested here that dye coupling, most probably medialed by gap junctions, is developmentally regulated. Coupling frequency decreased with the increase of chemical synapses (cf. Spira and Bennett, 1972). In the MOB, granule cells continue to be generated throughout a prolonged postnatal period (Altman, 1969; Bayer, 1983). In fact, a recent study suggests that the granule cell population in Charles River outbred rats linearly increases in total number throughout adult life ( 8800 cells/d; Kaplan et al., 1985); this remarkable continuation of the formation of granule cells parallels (1) the increase of synaptic space on mitral cells (Hinds and McNelly, 1977), (2) an increased olfactory input from an enlarged receptor cell population (Hinds and McNelly, 1981), and, possibly, (3) continued maintenance of intrabulbar and central afferent connections to the MOB (Andres, 1975). In respect to these population dynamics, the existence of gap junctions between granule cells may thus reflect the presence of immature neurons within the granule cell population of the MOB. The biological function of gap junctions between immature neurons is unknown, but they may be involved in cell-cell transfer of small messenger molecules (Fraser, 1985) critical to the sculpting of microcircuitry.

The mode of connectivity in clustered neurons of the granule cell type suggests that these mutually coupled neurons can be considered as micromodules involved in the modulation of signals of the MOB output neurons, which in turn act under the influence of convergent central limbic and olfactory-related inputs. The connectional scheme for these bipolar interneurons demonstrated in this report has formed a new basis for further studies of the nature of the gap junctions in the developing and mature mammalian MOB; thus, useful insights about the functional significance of CNS gap junctions might be gained from the elucidation of the histochemical features and physiological properties of the functional unit of the bulbar granule cell ag-

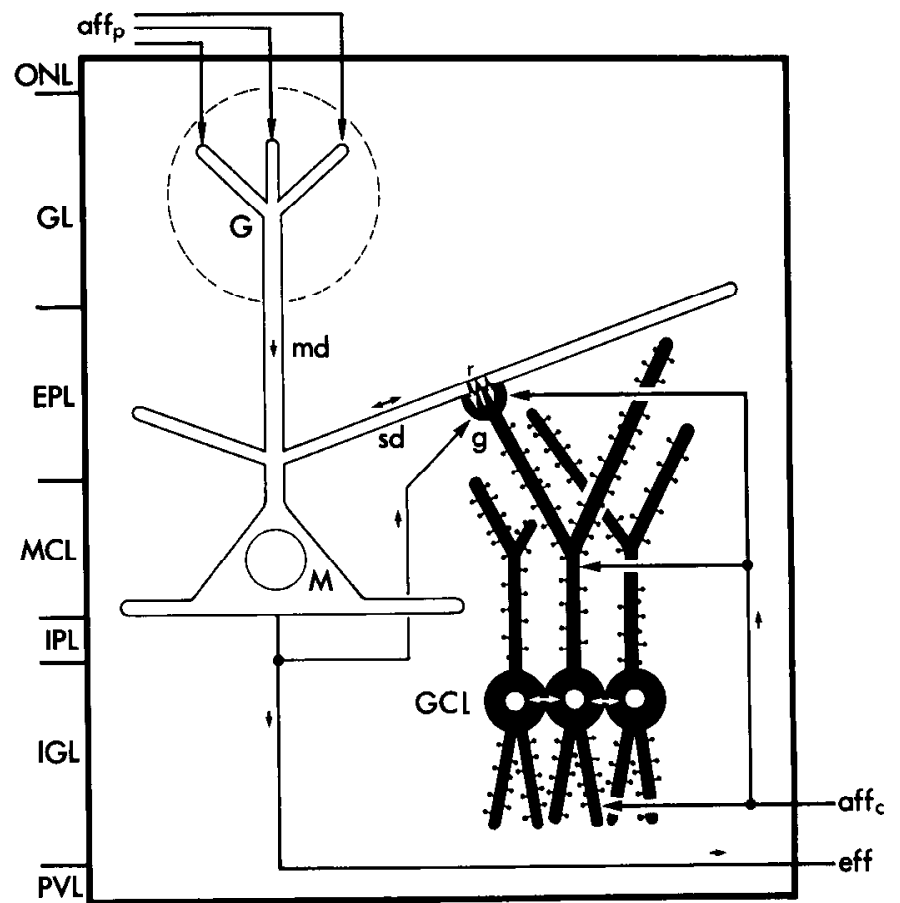

Figure 5. Summary diagram pointing to the presumed sites of chemical-synaptic junctions and electrotonic coupling via gap-junctional interperikaryal contacts between adjacent internal granule cells in the IGL (open arrows) and dendrodendritic gap junctions between granule and mitral cells in the EPL of the mammalian olfactory bulb. g. gemmulae; $G$, glomerulus; $G C L$, granule cell cluster; $G L$, glomerular/periglomerular layer; $M$, mitral cell; $M C L$, mitral cell layer; $m d$, main dendrite of mitral cell; $O N L$, olfactory nerve layer; $P V L$, periventricular layer; $r$, reciprocal synapse; $s d$, secondary dendrite of mitral cell; $a f f_{p}$, olfactory nerve afferents; $a f f_{c}$, centrifugal afferents; eff, centripetal efferents.

gregate system in respect to mechanisms governing maturation and input-output transformation.

\section{References}

Altman J (1969) Autoradiographic and histological studies of postnatal neurogenesis, IV. Cell proliferation and migration in the anterior forebrain, with special reference to persisting neurogenesis in the olfactory bulb. J Comp Neurol 137:433-457.

Andres KH (1965) Der Feinbau des Bulbus olfactorius der Ratte unter besonderer Berücksichtigung der synaptischen Verbindungen. Z Zellforsch 65:530-561.

Andres KH (1975) Neue morphologische Grundlagen zur Physiologie des Riechens und Schmeckens. Arch Oto-Rhino-Laryng 210:1-41.

Andrew RD, MacVikar BA, Dudek FE, Hatton GH (1981) Dye transfer through gap junctions between neuroendocrine cells of rat hypothalamus. Science 211:1187-1189.

Andrew RD, Taylor CP, Snow RW, Dudek FE (1982) Coupling in rat hippocampal slices. Brain Res Bull 8:211-222.

Austin L, Recasens M, Mandel P (1979) GABA in the olfactory bulb and olfactory nucleus of the rat: the distribution of gamma-aminobutyric acid, glutamic acid decarboxylase, GABA transaminase and succinate semialdehyde dehydrogenase. J Neurochem 32:1473-1477.

Baker $H$ (1986a) Species differences in the distribution of substance $\mathrm{P}$ and tyrosine hydroxylase immunoreactivity in the olfactory bulb. J Comp Neurol 252:206-226.

Baker H (1986b) Substance $P$ and tyrosine hydroxylase are localized in different neurons of the hamster olfactory bulb. Exp Brain Res 65: 245-249.

Bayer SA (1983) ${ }^{3} \mathrm{H}$-thymidine-radiographic studies of neurogenesis in the rat olfactory bulb. Exp Brain Res 50:329-340.

Benardo LS, Foster RE (1986) Oscillatory behavior in inferior olive neurons: mechanism, modulation, cell aggregates. Brain Res Bull 17: 773-784. 
Bennett MVL, Goodenough DA (1978) Gap junctions, electronic coupling, and intercellular communication. Neurosci Res Program Bull 33:371.

Bogan N, Brecha N, Gall C, Karten HJ (1982) Distribution of enkephalin-like immunoreactivity in the rat main olfactory bulb. Neuroscience 7:895-906.

Buhl EH, Lübke J (1989) Intracellular Lucifer yellow injection in fixed brain slices combined with retrograde tracing light and electron microscopy. Neuroscience 28:3-16.

Bullock TH (1945) Functional organization of the giant fiber system of Lumbricus. J Neurophysiol 8:55-71.

Burd GD, Davis BJ, Macrides F (1982) Ultrastructural identification of substance $P$ immunoreactive neurons in the main olfactory bulb of the hamster. Neuroscience 7:2697-2704.

Cobbett P, Ilatton GI (1984) Dye-coupling in hyphothalamic slices: dependence on in vivo hydration state and osmolarity of incubation medium. J Neurosci 4:3034-3038.

Connors BW, Benardo LS, Prince DA (1983) Coupling between neurons of the developing rat neocortex. J Neurosci 3:773-782.

Davis BJ, Burd GD, Macrides F (1982) Localization of methionineenkephalin, substance $\mathbf{P}$ and somatostatin immunoreactivities in the main olfactory bulb of the hamster. J Comp Neurol 204:377-383.

Dowling JE, Boycott BB (1966) Organization of the primate retina: electron microscopy. Proc R Soc Lond [Biol] 166:80-111.

Fraser S (1985) Gap junctions and cell interactions during development. Trends Neurosci 8:3-4.

Frazier-Cierpial LL, Brunjes PC (1989) Early postnatal differentiation of granule cell dendrites in the olfactory bulbs of normal and unilaterally odor-deprived rats. Dev Brain Res 47:129-136.

Golgi C (1875) Sulla fina struttura dei bulbi olfattori. In: Opera omnia, Vol 1, Histologia normale, pp 113-132.

Gutnick MJ, Prince DA (1981) Dye coupling and possible electrotonic coupling in the guinea pig neocortical slice. Science 211:67-70.

Halász N, Lungdahl A, Hökfelt T (1979) Transmitter histochemistry of the rat olfactory bulb. III. Autoradiographic localization of $\left({ }^{3} \mathrm{H}\right)$ GABA. Brain Res 167:221-240.

Heimer L, Rohards MJ (1982) Neuroanatomical tract-tracing methods, $2 d$ ed. New York: Plenum.

Hinds JW (1968a) Autoradiographic study of histogenesis in the mouse olfactory bulb. I. Time of origin of neurons and ncuroglia. J Comp Neurol 134:287-304.

Hinds JW (1968b) Autoradiographic study of histogenesis in the mouse olfactory bulb. II. Cell proliferation and migration. J Comp Neurol 134:305-321.

Hinds JW, Hinds PL (1976) Synapse formation in the mouse olfactory bulb. I. Quantitative studies. J Comp Neurol 169:15-40.

Hinds JW, McNelly NA (1977) Aging of the rat olfactory bulb: growth and atrophy of constituent layers and changes in size and number of mitral cells. J Comp Neurol 171:345-368.

Hinds JW, McNelly NA (1981) Aging in the rat olfactory system: correlation of changes in the olfactory epithelium and olfactory bulb. J Comp Neurol 203:441-453.

Jackowski A, Parnavelas JG, Lieberman AR (1978) The reciprocal synapse in the external plexiform layer of the mammalian olfactory bulb. Brain Res 159:17-28.

Jaffě EH, Cuello AC, Priestley JV (1983) Localization of ${ }^{3} \mathrm{H}-\mathrm{GABA}$ in the rat olfactory bulb: an in vivo and in vitro autoradiographic study. Exp Brain Res 50:100-106.

Kaplan MS, Hinds JW (1977) Neurogenesis in adult rat: electron microscopic analysis of light autoradiographs. Science 197:1092-1094.

Kaplan MS, McNelly NA, Hinds JW (1985) Population dynamics of adult-formed granule neurons of the rat olfactory bulb. J Comp Neurol 239:117-125.

Katsumaru H, Kosaka T, Heizmann CW, Hama K (1988) Gap junctions on GABAergic neurons containing the calcium-binding protein parvalbumin in the rat hippocampus (CA1 region). Exp Brain Res 72:363-370.

Kishi K (1987) Golgi studies on the development of granule cells of the rat olfactory bulb with reference to migration in the subependymal layer. J Comp Neurol 258:112-124.

Knowles WD, Funch PG, Schwartzkroin PA (1982) Electrotonic and dye coupling in hippocampal CA1 pyramidal cells in vitro. Neuroscience 7:1713-1722.

Kosaka (1983) Neuronal gap junctions in the polymorph layer of the rat dentate gyrus. Brain Res 277:347-351.
Kosaka T, Kosaka K, Heizmann CW, Nagatsu I, Wu J-Y, Yanaihara N, Hama K (1987) An aspect of the organization of the GABAergic system in the rat main olfactory bulb: laminar distribution of immunohistochemically defined subpopulations of GABAergic neurons. Brain Res 411:373-378.

Landis DMD, Reese TS, Raviola E (1974) Differences in membrane structure between excitatory and inhibitory components of the reciprocal synapse in the olfactory bulb. J Comp Neurol 155:67-92.

Larsen WJ, Tung HN, Murray SA, Swenson CA (1979) Evidence for the participation of actin microfilaments and bristle coats in the internalization of gap junction membrane. J Cell Biol 83:576-587.

Llinás R, Baker R, Sotelo C (1974) Electrotonic coupling between neurons in cat inferior olive. J Neurophysiol 37:560-571.

Macrides F, Eichenbaum HB, Forbes WB (1982) Temporal relationship between sniffing and the limbic rhythm during odor discrimination reversal learning. J Neurosci 2:1705-1717.

Matsutani S, Senba E, Tohyama M (1988) Neuropeptide- and neurotransmitter-related immunoreactivities in the developing rat olfactory bulb. J Comp Neurol 272:331-342.

Matsutani S, Senba E, Tohyama M (1989) Distribution of neuropeptide-like immunoreactivities in the guinea pig olfactory bulb. J Comp Neurol 280:577-586.

McLean JH, Shipley MT, Nickell WT, Aston-Jones G, Reyher CKH (1989) Chemoanatomical organization of the noradrenergic input from the locus coeruleus to the olfactory bulb of the adult rat. J Comp Neurol 285:339-349.

McLennan H (1971) The pharmacology of inhibition of mitral cells in the olfactory bulb. Brain Res 29:177-184.

Mori K, Kishi K (1982) The morphology and physiology of the granule cells in the rabbit olfactory bulb revealed by intracellular recording and HRP injection. Brain Res 247:129-133.

Mori K, Takagi SF (1978) An intracellular study of dendrodendritic inhibitory synapses on mitral cells in the rabbit olfactory bulb. $J$ Physiol (Lond) 279:569-588.

Mori K, Kishi K, Ojima H (1983) Distribution of dendrites of mitral, displaced mitral, tufted, and granule cells in the rabbit olfactory bulb. J Comp Neurol 219:339-355.

Mugnaini E, Wouterlood FG, Dahl A-L, Oertel WH (1984) Immunocytochemical identification of GABAergic neurons in the main olfactory bulb of the rat. Arch Ital Biol 122:83-113.

Nickell WT, Shipley MT (1988) Neurophysiology of magnocellular forebrain inputs to the olfactory bulb in the rat: frequency potentiation of field potentials and inhibition of output neurons. J Neurosci 8: 4492-4502.

Nicoll RA (1971) Pharmacological evidence for GABA as the transmitter in granule cell inhibition in the olfactory bulb. Brain Res 35: $137-149$.

Orona E, Scott JW, Rainer EC (1983) Different granule cell populations innervate superficial and deep regions of the external plexiform layer in rat olfactory bulb. J Comp Neurol 217:227-237.

Paul DL (1986) Molecular cloning of cDNA for rat liver gap junction protein. J Cell Biol 103:123-134.

Price JL, Powell TPS (1970a) The morphology of the granule cells of the olfactory bulb. J Cell Sci 7:91-123.

Price JL, Powell TPS (1970b) The synaptology of the granule cells of the olfactory bulb. J Cell Sci 7:125-155.

Price JL, Powell TPS (1970c) An electron microscopic study of the termination of the afferent fibres to the olfactory bulb from the cerebral hemisphere. J Cell Sci 7:157-187.

Rall W, Shepherd GM (1968) Theoretical reconstruction of field potentials and dendrodendritic synaptic interactions in olfactory bulb. J Neurophysiol 31:884-915.

Rall W, Shepherd GM, Reese TS, Brightman MW (1966) Dendrodendritic synaptic pathway for inhibition in the olfactory bulb. Exp Neurol 14:44-56.

Ramón y Cajal S (1911) Histologie du système nerveux de l'homme et des vertébrés, Pt 2. Paris: Maloine. Reprinted in: Institute Ramon y Cajal, 1955, p. 435. Madrid: Neudruck.

Raviola E, Gilula NB (1975) Intramembrane organization of specialized contacts in the outer plexiform layer of the retina. J Cell Biol 65:192-222.

Revel JP, Karnovsky MJ (1967) Hexagonal array of subunits in intercellular junctions of the mouse heart and liver. J Cell Biol 33:C7.

Reyher CKH (1987) Ultrastructural features of internal granule cells in the rat olfactory bulb. Chem Senses 12:199. 
Reyher CKH (1988) Persistence of the pars externa system of the anterior olfactory nucleus in a microsomatic primate, Callithrix jacchus. Brain Res 457:169-175.

Reyher CKH, Schwerdtfeger WK, Baumgarten HG (1988) Interbulbar axonal collateralization and morphology of anterior olfactory nucleus neurons in the rat. Brain Res Bull 20:549-566.

Ribak CE, Vaughn JE, Saito K, Barber R, Roberts E (1977) Glutamate decarboxylase localization in neurons of the olfactory bulb. Brain Res 126:1-18.

Scheibel ME, Scheibel AB (1975) Dendrite bundles, central programs and the olfactory bulb. Brain Res 95:407-421.

Schmalbruch H, Jahnsen H (1981) Gap junctions on CA3 pyramidal cells of guinea pig hippocampus shown by freeze-fracture. Brain Res 217:175-178.

Schneider SP, Macrides F (1978) Laminar distributions of interneurons in the main olfactory bulb of the adult hamster. Brain Res Bull 3:73-82.

Shepherd GM (1972) Synaptic organization of the mammalian olfactory bulb. Physiol Rev 52:864-917.

Shepherd GM (1979) The synaptic organization of the brain, 2d ed, pp 1-435. Oxford: Oxford UP.

Shiosaka S, Yamamoto T, Hertzberg EL, Nagy JI (1989) Gapjunction protein in rat hippocampus: correlative light and electron microscope immunohistochemical localization. J Comp Neurol 281:282-297.

Sotelo C, Llinás R (1972) Specialized membrane junctions between neurons in the vertebrate cerebellar cortex. J Cell Biol 53:271-289.

Sotelo C, Llinás R, Baker R (1974) Structural study of inferior olivary nucleus of the cat: morphological correlates of electronic coupling. J Neurophysiol 37:541-559.

Spira ME, Bennett MVL (1972) Synaptic control of electrotonic coupling between neurons. Brain Res 37:294-300.

Stewart WW (1978) Functional connections between cells as revealed by dye-coupling with a highly fluorescent naphthalimide tracer. Cell 14:741-759.

Stewart WW (1981) Lucifer dyes-highly fluorescent dyes for biological tracing. Nature 292:17-21.

Struble RG, Walters CP (1982) Light microscopic differentiation of two populations of rat olfactory bulb granule cells. Brain Res 236: 237-251.

Valverde F (1965) Studies on the piriform lobe, pp 50-54. Cambridge, MA: Harvard UP.

Yamamoto T, Shiosaka S, Whittaker ME, Hertzberg EL, Nagy JI (1989) Gap junction protein in rat hippocampus: light microscope immunohistochemical localization. J Comp Neurol 281:269-281. 